\title{
PERANCANGAN SISTEM INFORMASI UNTUK PENGELOLAAN KINERJA PEGAWAI DAN JEMAAT DI GEREJA MASEHI ADVENT HARI KE-TUJUH UNI INDONESIA BAGIAN BARAT
}

\author{
Henry Pandia \\ Fakultas Teknologi Informasi, Universitas Advent Indonesia
}

\begin{abstract}
Abstrak
Pengukuran kinerja pegawai merupakan sebuah pekerjaan yang sulit tetapi harus dilakukan jika organisasi ingin dapat mengelola dan mengembangkan kinerja para pegawainya. Karena itu, sebuah sistem informasi perlu dikembangkan untuk mendukung organisasi untuk merekam data kinerja pegawai secara efektif. Gereja Masehi Advent Hari Ketujuh (MAHK) Uni Indonesia Kawasan Barat (UIKB) merupakan sebuah organisasi yang mempunyai ratusan pegawai yang tersebar di delapan Konfrens/Daerah yang terpisah secara regional, membutuhkan sebuah sistem berbasis teknologi informasi yang dapat digunakan untuk mengumpulkan, merekam seluruh data aktivitas dan pelayanan dari Pendeta Jemaat sebagai pegawai dan Jemaat dimana pegawai tersebut ditempatkan. Sistem tersebut akan membantu manajemen puncak untuk mendapatkan informasi yang sesuai dan lengkap dalam proses pengambilan kebijakan dan kebutuhan serta promosi karir pegawai. Penelitian ini bertujuan untuk mengembangkan sebuah sistem yang memenuhi kebutuhan organisasi gereja MAHK di Uni Indonesia Bagian Barat menggunakan metode System Development Life Cycle (SDLC), metode yang umum digunakan dalam pengembangan sistem informasi menggunakan model Waterfall dengan tahapan-tahapan berikut: (1) Requirement Analysis, (2) Design (3) Implementation (4) Testing (5) Maintenance. Hasil dari penelitian ini adalah sebuah sistem informasi berbasis web yang dapat digunakan oleh Organisasi MAHK Uni Indonesia Kawasan Barat untuk merekam, menyimpan dan menyebarkan data dan informasi dari aktivitas, layanan dan kinerja dari Pendeta jemaat dan Jemaat yang tersebar di seluruh Indonesia Kawasan Barat.
\end{abstract}

Kata-kata kunci: Sistem Informasi, Kinerja, Desain System

\section{DEVELOPMENT OF INFORMATION SYSTEM FOR EMPLOYEE'S AND CHURCH'S PERFORMANCE IN SEVENTH DAY ADVENTIST CHURCH WEST UNION MISSION}

\begin{abstract}
Measuring employee productivity is a difficult task but a must if an organization want to managae and improve its employee performance. Therefore, and information system is needed which support organization in employee's data recording process effectively. West Indonesian Union Mission (WIUM) is an organization that have hundreds employee that distributed in eight conferences/fields mission regionally separated, needs an information technology based system to acquire data and record all church's and church pastor's activities and services. The system will assist top management by giving adequate information in process of policy and decision making as well as careers promotion. Research aimed to develop a system that match WIUM's requirements using System Development Life Cycle (SDLC) method, most popular method in information system development. Model that used in system development is waterfall model with stage: (1) Requirement Analysis, (2) Design (3) Implementation (4) Testing and (5) Maintenance. Result of Research is a web based information system that WIUM can use to record, store and share data and information of church's and church pastor's activities, services and performance.
\end{abstract}

Key words: Information Systems, Performance, System Design 


\section{Pendahuluan}

Gereja Masehi Advent Hari Ketujuh (MAHK) Uni Indonesia Kawasan Barat (UIKB) merupakan sebuah organisasi keagamaan yang mempunyai gereja-gereja yang tersebar di seluruh Indonesia Kawasan Barat yang mencakup Sumatera, Jawa, Bali, Nusa Tenggara Barat dan Timur, Kalimantan dan pulau-pulau kecil lainnya di bagian Barat Indonesia. Gereja-gereja tersebut di kelompokkan dalam unit pelayanan yang lebih kecil yang disebut dengan Konfrens atau Daerah Misi. Ada delapan Daereah Misi dan 3 konfrens yang berada di bawah managemen Gereja MAHK UIKB.

Dalam usaha peningkatan pelayanan organisasi gereja terhadap anggota jemaat, maka UIKB berusaha meningkatkan pelayanan yang diberikan oleh pendeta jemaat kepada masing-masing anggota gereja. Meskipun sulit dilakukan, pengukuran kinerja pendeta jemaat sebagai pegawai organisasi di lingkungan UIKB mutlak harus dilakukan agar dapat meningkatkan kinerja para pegawai tersebut. Pengukuran kinerja dapat juga dilihat memberikan pengaruh langsung dari kepuasan kerja dan motivasi dari pegawai (Ahmad. R, \& Ali, NZ, 2004). Sehingga jika diperlukan organisasi UIKB dapat memberikan Teknik motivasi yang lebih baik untuk perbaikan kinerja para pendeta. Karena itu, untuk mengukur kinerja pegawai, UIKB telah menetapkan indikator-indikator kemajuan gereja dan digunakan sebagai dasar penilaian kinerja pendeta. Setiap tahun UIKB melalui konfrens dan Daerah Misi menetapkan target pencapaian yang menjadi tujuan dari setiap pendeta di jemaat-jemaat. Dan berdasarkan hasil pencapaian pada indicator tersebut, maka kinerja seorang pendeta jemaat akan diukur.

Pada sistem yang berjalan saat ini, untuk mendapatkan data indikator pencapaian, maka setiap pendeta jemaat diwajibkan untuk memberikan laporan-laporan pencapaian secara berkala, baik setiap bulan, triwulan, semester dan akhir tahun. Pelaporan dilakukan dengan cara setiap pendeta mengisi form laporan yang sudah disediakan oleh konfrens atau Daerah Misi. Konfrens/Daerah Misi kemudian merekapitulasi laporan dari pendeta jemaat dan kemudian menjadikannya sebagai laporan dari konfrens/daerah misi ke UIKB.

Ada beberapa kelemahan dari sistem pelaporan yang ada saat ini, antara lain: (1) Pendeta jemaat sering terlambat dalam memberikan laporan (2), sistem penyimpanan data kinerja pendeta dan jemaat tidak tersimpan dengan baik dan sulit melihat histori dari kinerja pendeta dan jemaat. (3) Akses kinerja pendeta dan jemaat sulit dilakukan (4) Kinerja pendeta jemaat jarang digunakan sebagai dasar untuk promosi jabatan karena data kinerja tidak direkam dan disimpan secara baik dan sulit diakses (5) Top managemen di UIKB sulit mengakses data ketika akan membuat keputusan.

Mengacu kepada problem bisnis di atas, maka diperlukan sebuah sistem informasi yang dapat digunakan untuk merekam, menyimpan, mengolah, dan membagikan data dan informasi terkait aktivitas dan kinerja pendeta jemaat dan jemaat. Data dan informasi yang direkam dan disimpan kemudian dapat digunakan oleh pihak manajemen sebagai indikator kinerja Pendeta Jemaat dan Jemaat yang ada dalam lingkungan organisasi Gereja Masehi Advent Hari Ketujuh Indonesia Kawasan Barat. Pengukuran kinerja dan pemberian penghargaan yang akurat terhadap kinerja pegawai organisasi akan memberikan pengaruh kepada kepuasan dan motivasi kepada pegawai (Ahmad. R, \& Ali. NZ, 2004).

\section{Problem Statement}

Penelitian ini dilakukan untuk mengembangkan sebuah sistem informasi yang dapat digunakan oleh MAHK UIKB untuk mengukur kinerja pendeta jemaat. Kinerja pendeta jemaat diukur berdasarkan pada indikator kinerja aktivitas pelayanan dan kemajuan jemaat. Sistem informasi yang dikembangkan akan digunakan untuk merekam, menyimpan, mengolah, membagi dan melaporkan data aktivitas pelayanan dan indikator kemajuan jemaat. Selain itu, Sistem yang dikembangkan akan dapat membantu manajemen untuk mengambil keputusan dan kebijakan terkait pemberian penghargaan dan promosi kepada pegawai berbasis kinerja dan kebijakan untuk kemajuan organisasi.

\section{Metodologi Penelitian}

Pada proyek pengembangan sistem informasi, model Waterfall merupakan model yang paling banyak dijadikan referensi (Huo et al., 2004; Jiang \& Eberlein, 2008). Walaupun pendekatan Waterfall sering dikritik dalam merespon perubahan lingkungan yang kadang tidak menentu dan fleksibel, karena karakternya yang kaku (Nerur \& Balijepally, 2007). Meskipun akar penyebab kritikan tersebut dapat dipahami namun model Waterfall tetap dianggap mempunyai kelebihan dan dengan pengelolaan dan pendekatan yang baik, model tersebut masih berperan banyak dalam pengembangan dan implementasi sistem informasi. Tahapan- 
tahapan yang digunakan dalam penelitian ini mengacu kepada pendekatan model Waterfal/dengan tahapan sebagai berikut:

\section{a. Requirement Analysis}

Requirement analysis merupakan tahapan untuk mendapatkan kebutuhan sistem dan merupkan tahapan pertama dalam pengembangan sebuah sistem informasi. Ada beberapa Teknik yang digunakan pada fase ini.

\section{b. Identifikasi}

Identifikasi kebutuhan dilakukan untuk mendapatkan data dan informasi terkait kegiatan presensi. Teknik yang digunakan dalam identifikasi kebutuhan dalam penelitian ini adalah sebagai berikut:

1. Interview

Proses peengumpulan kebutuhan dengan cara melakukan interview dengan pengguna dan menejemen organisasi. Pada penelitian ini, interview dilakukan dengan pendeta jemaat, direktur departemen di konfrens/daerah misi serta direktur departemen dan pimpinan di UIKB.

2. Document Analysis:

Analisa dokumen dilakukan dengan cara menganalisa dokumen-dokumen yang digunakan saat ini untuk mendapatkan kebutuhan sistem. Dokumen yang dianalisa berupa form isian dan pelaporanpelaporan.

Analisis Kebutuhan Data yang telah terkumpul selanjutnya dianalisa dan kemudian merumuskan solusi untuk memecahkan permasalahan yang ada. Dalam tahap ini hal-hal yang perlu dianalisa adalah hambatan yang dialami, pengguna sistem, dan fungsi yang ditangani sistem.

\section{c. Model Design}

Pada tahapan ini dilakukan pengembangan model sistem dengan cara memodelkan kebutuhan sistem yang sudah diperoleh pada tahap sebelumnya. Model yang digunakan antara lain adalah use case diagaram, activity diagram, class diagram, sequence diagram, ER-diagram.

\section{d. Pembangunan Sistem}

Pada tahapan pengembangan sistem atau coding, maka model yang dibuat pada tahap model desain diterejemahkan untuk menjadi tampilan antarmuka, membuat database sistem dan menuliskan kode-kode program.

\section{Pengujian dan Evaluasi Sistem}

Tahap pengujian sistem dilakukan untuk mengecek apakah semua fungsi yang ada di sistem sudah bekerja dengan baik. Pengujian fungsi dilakukan dengan cara memberikan masukan secara random dan masukan sistem pada titik ekstrim dan melihat apakah keluaran sistem dapat bekerja dengan baik

Tahap evaluasi sistem dilakukan untuk mengukur apakah sistem yang dikembangkan dapat menjadi solusi bisnis bagi organisasi mengatasi masalah yang ada saat ini.

\section{Pengembangan Sistem}

Proses pengembangan sistem dilakukan dengan langkah-langkah seperti yang sudah dibahas pada bagian metodologi penelitian. Hasil dari proses tersebut akan dijelaskan tahap demi tahap di bawah ini:

\section{Analisa Kebutuhan}

Tahapan Analisa kebutuhan dilakukan untuk mendapatkan kebutuhan sistem mencakup kebutuhan fungsi, kebutuhan data, kebutuhan jaringan, infrastruktur teknologi dan sebagainya. Analisa kebutuhan dapat dilakukan dengan berbagai cara, namun pada penelitian ini tahapan ini dilakukan dengan beberapa cara yaitu: interview, rapat dan Analisa dokumen. Hasil dari masing-masing teknik tersebut adalah sebagai berikut:

\section{Interview}

Interview dilakukan kepada masing-masing user yang akan menggunakan sistem yang akan dikembangkan. Hasil dari interview tersebut adalah berupa pemahaman permasalahan yang sering muncul saat ini dan harapan-harapan dari masing-masing user. Selain itu, interview juga diperoleh kebutuhan data dan informasi dari masing-masing user. 


\section{Board Meeting}

Board meeting dilakukan dengan mengumpulkan semua dokumen yang terkait dengan proses yang ada di organisasi dan kemudian menganalisa dokumen-dokumen tersebut. Dokumen yang terlibat antara lain: form laporan bulanan, triwulan, semester dan akhir tahun dari masing-masing pendeta jemaat, laporan bulanan jemaat, laporan triwulan jemaat, laporan tahunan jemaat, laporan perpuluhan dan laporan baptisan. Hasil Analisa dokumen tersebut diperoleh pemahaman akan proses yang ada saat ini dan kebutuhan data dan informasi pada tiap-tiap proses tersebut.

Setelah melakukan tahapan di atas, maka hasil yang diperoleh kemudian dianalisa dan diterjemahkan menjadi kebutuhan-kebutuhan sistem. Kebutuhan sistem mencakup kebutuhan data dan informasi dari masing-masing pengguna, kebutuhan fungsi di sistem dan kebutuhan akses dari masing-masing user. Adapun kebutuhan fungsi di sistem adalah sebagai berikut:

1. Input perpuluhan dan persembahan jemaat

2. Input baptisan di jemaat

3. Input kegiatan jemaat

4. Input anggota baru

5. Input perpindahan anggota

6. Input mutasi anggota

7. Input kegiatan pendeta

8. Input care grpuo

9. Input cluster/distrik

10. Input pendeta

11. Input jemaat

12. Tampilkan Laporan Baptisan seKonfrens/Daerah

13. Tampilkan Laporan Perpuluhan dan perpuluhan seKonfrens/Daerah

14. Tampilkan Laporan Kegiatan Jemaat se Konfrens/Daerah

15. Tampilkan laporan kegiatan pendeta se Konfrens/Daerah

16. Tampilkan laporan Keanggotaan se Konfrens/Daerah

17. Input Konfrens/Daerah

18. Tampilkan Laporan Baptisan se UIKB

19. Tampilkan Laporan Perpuluhan dan perpuluhan se UIKB

20. Tampilkan Laporan Kegiatan Jemaat se UIKB

21. Tampilkan laporan kegiatan pendeta se UIKB

22. Tampilkan laporan Keanggotaan se UIKB

\section{Pemodelan Sistem}

Hasil dari proses analisa kebutuhan kemudian digunakan pada proses pemodelan sistem. Pada penelitian ini, proses pemodelan sistem dilakukan dengan menggunakan Unified Modelling Language (UML). UML dipilih karena kemampuannya untuk memodelkan spesifikasi, visualisasi dan dokumentasi sistem pada fase pengembangan [Eriksson dan Penker, 1998]. Selain itu, UML juga memiliki kemampuan untuk memvisualisasikan dan mendokumentasikan hasil analisa dan desain yang berisi sintak dalam memodelkan sistem secara visual (Braun, et. al., 2001). kemampuan di atas memungkinkan orang-orang yang terlibat dalam pengembangan sistem dapat berkomunikasi dengan baik dan menghindari defect dalam pengembangan sistem. Selain untuk alasan komunikasi antar anggota tim, pemodelan juga digunakan untuk alasan dokumentasi dan perencanaan yang baik.

Setelah menetapkan kebutuhan sistem dan fungsi pada tahap analisa kebutuhan, maka pada tahap pemodelan ini dikembangkan model-model sistem menggunakan model-model yang dimiliki oleh UML. Beberapa model UML yang digunakan pada penelitian ini adalah sebagai berikut:

\section{Activity Diagram}

Activity diagram merupakan model UML yang digunakan untuk menunjukkan rangkaian aktivitas di dalam sistem. Activity digram menampilkan bagaimana aliran satu aktivitas ke aktivitas yang lain dan bagaimana aktivitas-aktivitas tersebut tersebut dikendalikan di dalam sistem. 


\section{Sequence Diagram}

Sequence diagram digunakan untuk memodelkan aliran perintah atau pesan dari satu kelas ke kelas yang lain di dalam program. Sequence diagram dibuat dengan mengacu kepada class diagram dan activity diagram yang sudah dibuat di atas. Sequence diagram pada sistem yang dibangun mewakili satu fungsi di dalam sistem.

\section{Class Diagram}

Class diagram digunakan untuk memodelkan kelas yang ada di dalam sistem dan hubungan antar masing-masing kelas. Pada sistem pengelolaan kinerja yang dikembangkan, terdapat kelas anggota, pegawai, gereja, konfrens/daerah, perpuluhan/persembahan, dan kegiatan.

\section{ER-Diagram}

Kebutuhan data yang ada di dalam sistem dimodelkan dengan model data konseptual. Model data konseptual tersebut tersebut kemudian diterjemahkan menjadi model data fisik (PDM). Selanjutnya model data fisik tersebut akan diterjemahkan menjadi kode-kode SQL Data Definition Language (DDL). Model data konseptual yang dibangun ditujukkan dalam bentuk Entity Relation Diagram. Dengan mengacu kepada pada ER-Diagram, database sistem dikembangkan.

\section{GUI Design}

Pada tahap ini, dilakukan perancangan tampilan antar muka sistem untuk masing-masing fungsi yang sudah diidentifikasi pada tahapan sebelumnya. Masing-masing tampilan didesain dengan mengacu kepada kebutuhan data yang akan diinput atau ditampilkan pada antar muka tersebut. Karena itu, hasil desain tampilan tersebut akan sangat ditentukan oleh model use case diagram dan ER diagram yang sudah dibuat pada tahapan sebelumnya. Desain antar muka kemudian diterjemahkan menjadi tampilan aplikasi.

\section{Pengkodean dan Pengujian}

Tahapan selanjutnya dalam sebuah proses pengembangan sistem informasi adalah tahap pengkodean (coding). Pada tahapan ini, model-model UML yang sudah dibuat pada tahapan sebelumnya diterjemahkan menjadi kode-kode program yang siap di deplo menjadi sebuah aplikasi yang siap dijalankan. Pada sistem yang dikembangkan ini, aplikasi yang dibangun adalah aplikasi berbasis web yang akan ditempatkan di sebuah server web di Internet dan dapat dijalankan diperangkat yang terhubung ke Internet menggunakan browser. Beberapa tampilan antarmuka yang paling utama yang dihasilkan dari proses pengkodean akan ditunjukkan di bawah ini.

\section{Fungsi Input Kegiatan Pendeta}

Fungsi Input Kegiatan pendeta digunakan untuk merekam kegiatan pendeta jemaat di masingmasing gereja. Fungsi tersebut digunakan oleh Pendeta jemaat untuk melaporkan kegiatan yang dilakukan. Data dari kegiatan pendeta jemaat tersebut akan direkam, disimpan dan dijadikan laporan kegiatan pendeta jemaat oleh sistem. Tampilan fungsi input kegiatan pendeta dapat dilihat pada Gambar 1 di bawah ini. 


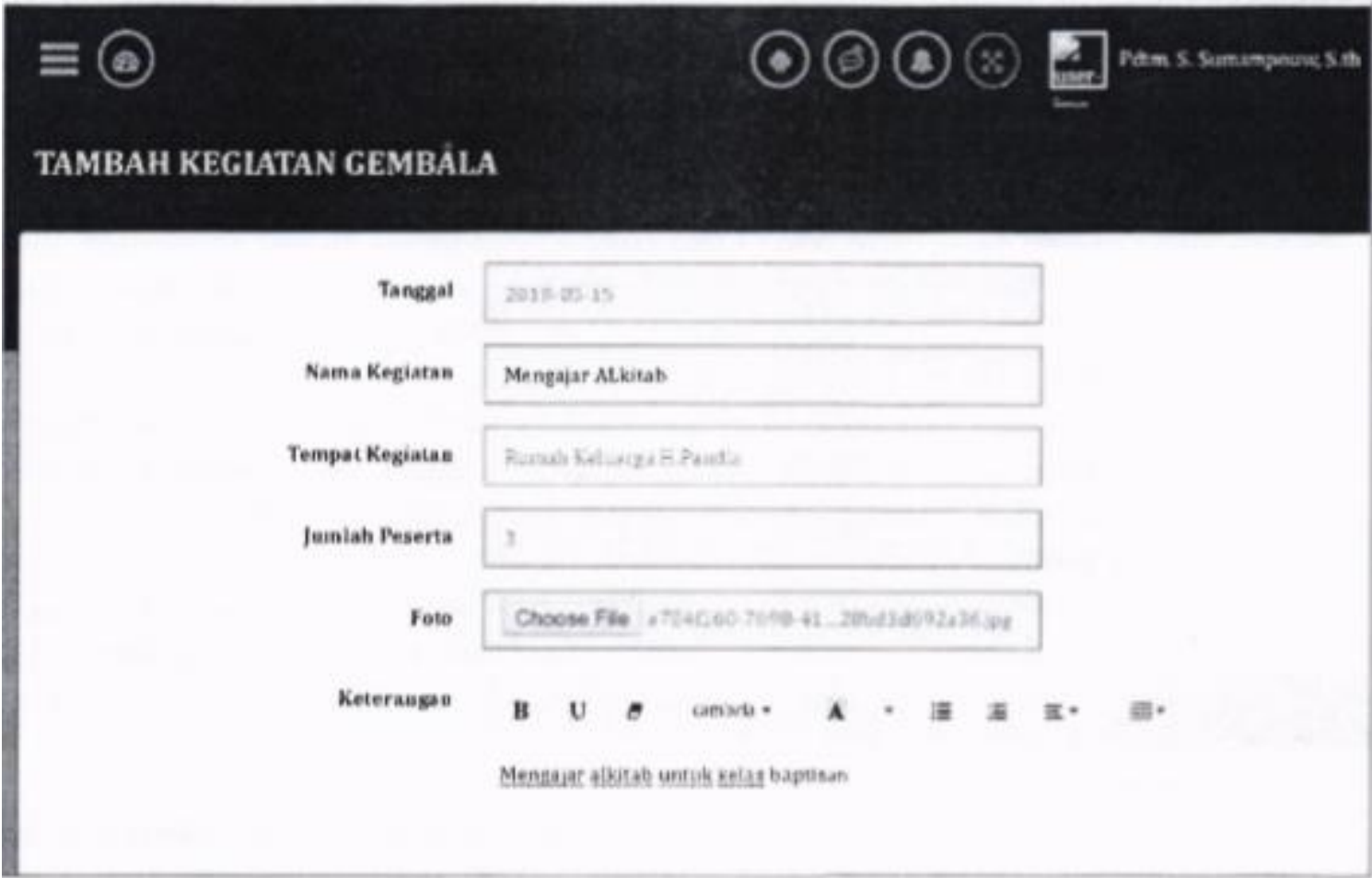

Gambar 1 Tampilan fungsi input kegiatan pendeta jemaat

\section{Fungsi Input Kegiatan Jemaat}

Fungsi Input kegiatan jemaat adalah fungsi yang digunakan oleh sekretaris jemaat atau pendeta jemaat untuk melaporkan kegiatan jemaat. Data-data kegiatan jemaat yang diinput akan disimpan dan digunakan sebagai laporan kegiatan jemaat dan sebagai alat ukur kinerja jemaat. Tampilan fungsi input kegiatan jemaat dapat dilihat pada Gambar 2 di bawah ini. 


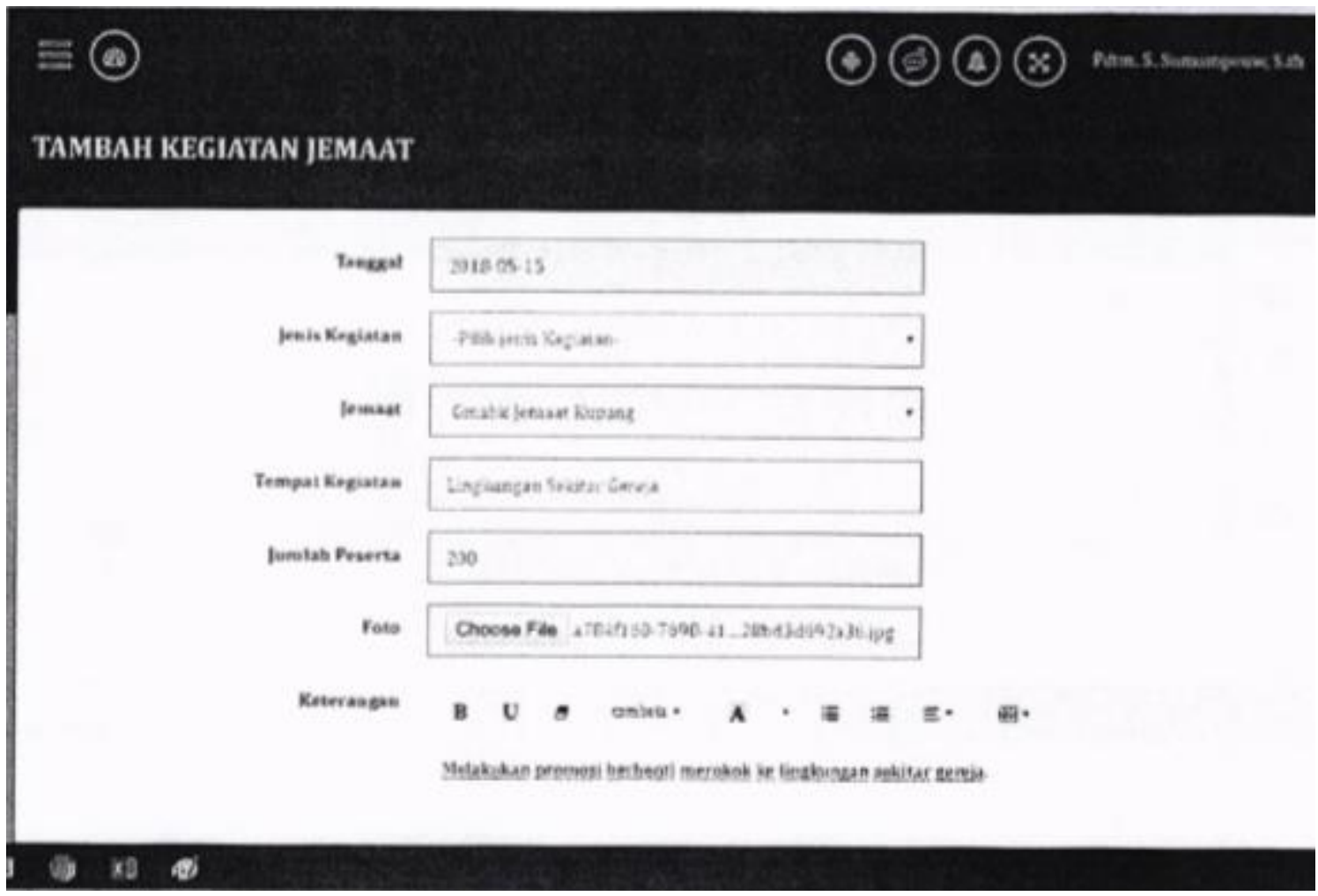

\section{Fungsi Input Persembahan dan Persepuluhan}

Gambar 2 Tampilan fungsi Input kegiatan jemaat

Fungsi Input persembahan dan perpuluhan digunakan oleh pendeta atau bendahara jemaat untuk melaporkan jumlah penerimaan persembahan dan perpuluhan di jemaat pada setiap kebaktian. Fungsi ini memungkinkan data persembahan dan perpuluhan dapat dicatat ke dalam sistem dan dilaporkan ke Konfrens/Daerah Misi dan UIKB.

\section{Fungsi Laporan Kegiatan Pendeta Jemaat di Daerah/Konfrens}

Fungsi laporan kegiatan pendeta jemaat digunakan Daerah/Konfrens untuk melihat kinerja dari masingmasing pendeta jemaat yang ditempatkan di tiap-tiap jemaat. Semua kegiatan pendeta jemaat akan direkam dan dilaporkan dalam bentuk format yang sudah disesuaikan, sehingga manajemen di Daerah/Konfrens dapat mengukur kinerja dari setiap pendeta jemaat.

\section{Fungsi Laporan Kegiatan Jemaat di Daerah/Konfrens}

Fungsi laporan kegiatan jemaat digunakan oleh Daerah/Konfrens untuk melihat semua kegiatan dari sebuah jemaat pada jangka waktu tertentu. Laporan ini dapat digunakan sebagai indikator keaktifan dari sebuah jemaat dan bagaimana kinerja pendeta jemaat mengelola jemaat yang dilayaninya.

\section{Fungsi Laporan Persembahan dan Persepuluhan di Daearh Konfrens}

Fungsi ini digunakan oleh Daerah/Konfrens untuk melihat pencapaian persembahan dan perpuluhan dari sebuah jemaat. Daerah/Konfrens dapat melihat apakah sebuah jemaat sudah mencapai target penerimaan yang sudah ditetapkan atau belum dari waktu ke waktu sepanjang tahun anggaran berjalan.

\section{Fungsi Laporan Persembahan Persepuluhan di Pusat}

Fungsi laporan persembahan dan perpuluhan juga digunakan oleh manajeme pusat di kantor UIKB. Fungsi laporan ini dapat menampilkan pencapaian persembahan dan perpuluhan dari setiap daerah/konfrens sehingga manajemen pusat dapat mengukur kinerja dari setiap daerah/konfrens yang ada. Jika diinginkan fungsi laporan ini memungkinkan manajemen pusat dapat melihat secara detail penerimaan persembahan dan persepuluhan di tiap-tiap jemaat daerah sebuah daerah/konfrens yang ada. 


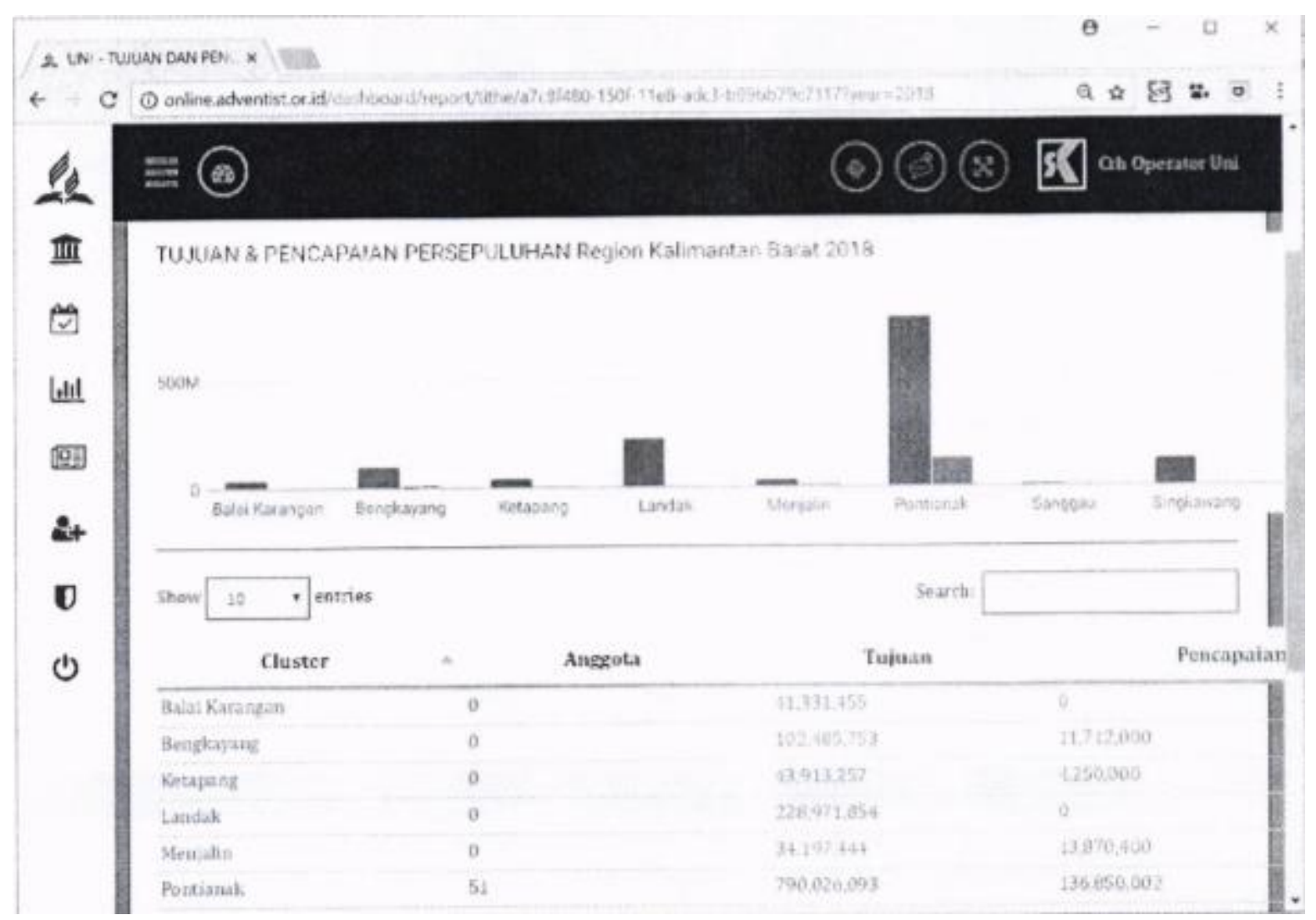

Gambar 3 Laporan Perpuluhan di Konfren/Daerah

Pengujuan sistem dilakukan untuk melihat apakah sistem dapat bekerja dengan kinerja yang diharapkan. Pengujian sistem dilakukan dengan cara menguji fungsi-fungsi yang ada. Pengujian fungsi ini dilakukan dengan menggunakan metode pengujuan black box dan white box. Pengujian white box dilakukan dengan cara menelusuri kode-kode program dan memastikan kode program tidak memiliki bug dan bekerja sesuai dengan proses yang diinginkan. Selanjutnya dilakukan pengujian black box, pengujian yang dilakukan dengan cara memberikan berbagai besaran masukan terutama pada ambang bata data dan pada titik ekstrim data. Pengujian ini dilakukan untuk menguji bagaimana masing-masing fungsi bekerja dan melihat hasil yang diberikan apakah bekerja sebagaimana seharusnya atau tidak. Hasil pengujian fungsi-fungsi sistem ditampilkan pada Tabel 1 di bawah ini:

Tabel 1 Hasil pengujian fungsi sistem

\begin{tabular}{|c|l|r|}
\hline No & User/Fungsi & Hasil \\
\hline & Fungsi di Level Jemaat & Berhasil \\
\hline 1 & Input perpuluhan dan persembahan jemaat & Berhasil \\
\hline 2 & Input baptisan di jemaat & Berhasil \\
\hline 3 & Input kegiatan jemaat & Berhasil \\
\hline 4 & Input anggota baru & Berhasil \\
\hline 5 & Input perpindahan anggota & Berhasil \\
\hline 6 & Input mutase anggota & Berhasil \\
\hline 7 & Input kegiatan pendeta & Berhasil \\
\hline 8 & Input care groups & Berhasil \\
\hline & Fungsi di Level Konfrens/Daerah & Berhasil \\
\hline 9 & Input cluster/distrik & Berhasil \\
\hline 10 & Input Pendeta & \\
\hline 11 & Input Jemaat &
\end{tabular}




\begin{tabular}{|r|l|r|}
\hline 12 & Tampilkan Laporan Baptisan se Konfrens/Daerah & Berhasil \\
\hline 13 & Tampilkan Laporan Perpuluhan dan perpuluhan se-Konfrens/Daerah & Berhasil \\
\hline 14 & Tampilkan Laporan Kegiatan Jemaat se-Konfrens/Daerah & Berhasil \\
\hline 15 & Tampilkan laporan kegiatan pendeta se-Konfrens/Daerah & Berhasil \\
\hline 16 & Tampilkan laporan Keanggotaan se-Konfrens/Daerah \\
\hline & Fungsi di Level Pusat & Berhasil \\
\hline 17 & Input Konfrens/Daerah & Berhasil \\
\hline 18 & Tampilkan Laporan Baptisan se UIKB & Berhasil \\
\hline 19 & Tampilkan Laporan Perpuluhan dan perpuluhan se UIKB & Berhasil \\
\hline 20 & Tampilkan Laporan Kegiatan Jemaat se UIKB & Berhasil \\
\hline 21 & Tampilkan laporan kegiatan pendeta se UIKB & Berhasil \\
\hline 22 & Tampilkan laporan Keanggotaan se UIKB &
\end{tabular}

\section{Evaluasi Sistem}

Mengacu pada hasil pengujian yang sudah dilakukan, fungsi-fungsi yang ada di dalam sistem dapat bekerja dengan sebagaimana yang diharapkan oleh pengguna. Fungsi yang dimiliki dapat membantu organisasi memecahkan berbagai permasalahan bisnis yang sering timbul selama ini.

Masalah-masalah organisasi yang dapat diselesaikan oleh sistem yang dikembangkan antara lain:

1. Kegiatan dari pendeta jemaat dan kegiatan jemaat dapat dilaporkan secara real time dan mengurangi kemungkinan terjadinya pelaporan yang terhambat

2. Sistem pelaporan yang lebih akurat dan mengurangi kemungkinan manipulasi pelaporan kegiatan oleh pendeta jemaat.

3. Manajemen organisasi di daerah dan pusat dapat memantau kinerja pendeta jemaat di setiap jemaat di masing-masing wilayah kerjanya.

4. Sistem dapat merekam dan menyimpan rekam jejak dan kinerja pendeta jemaat dan akan dapat digunakan untuk melakukan promosi dan penghargaan kepada pendeta jemaat.

5. Sistem dapat membuat administrasi dan pelaporan baptisan dengan lebih baik.

6. Sistem dapat membuat administrasi dan laporan persembahan dan persepuluhan dengan lebih baik.

7. Manajemen di daerah dan pusat dapat memantau pencapaian target baptisan, persembahan dan persepuluhan dengan lebih mudah.

8. Data dan informasi dari sistem dapat digunakan oleh manajemen di daerah dan pusat untuk membuat kebijakan, peraturan dan program-program.

Selain keuntungan penggunaan sistem di atas, sistem administrasi, pelaporan, dan pencatatan rekam jejak dari masing-masing pendeta jemaat dan daerah-daerah pelayanan, akan membuat pengelolaan organisasi menjadi lebih baik. Pengambilan keputusa, pemberian penghargaan dan peringatan, promosi jabatan dapat dilakukan dengan data dan informasi yang lebih baik.

\section{Kesimpulan Dan Saran}

Penelitian ini dilakukan dengan hipotesa awal bahwa aplikasi yang dibangun akan dapat memudahkan pegawai organisasi dalam hal ini pendeta jemaat dapat memberikan laporan kegiatan pelayanan dan kegiatan dari jemaat masing-masing. Selain itu, sistem ini akan memudahkan manajemen di tingkat daerah maupun di organisasi pusat dapat memantau kegiatan dari setiap pendeta jemaat dan jemaat yang ada dengan lebih baik, baik secara histori pekerjaan maupun pembuatan laporan. Berdasarkan hasil evaluasi sistem yang sudah dikembangkan, maka dapat disimpulkan bahwa:

1. Sistem yang dikembangkan dapat memberi kemudahan kepada pendeta jemaat membuat laporan kegiatan pelayanan yang dilakukan setiap hari.

2. Sistem yang dikembangkan dapat memberikan kemudahan kepada pendeta jemaat, sekretaris jemaat dan bendahara jemaat dalam pemberian laporan terkait kegiatan dan keadaan jemaat.

3. Sistem dapat memenuhi kebutuhan manajemen organisasi untuk memantau kegiatan pendeta jemaat dan kegiatan jemaat dengan lebih mudah.

4. Sistem dapat merekam, menyimpan data, dan membuat histori data kegiatan pendeta jemaat dan kegiatan jemaat

5. Sistem dapat membantu pihak manajemen dengan cara menyediakan data dan informasi yang akurat dan mudah diakses untuk keperluan pengambilan keputusan. 
Meskipun sistem yang dikembangkan sudah dapat memenuhi berbagai kebutuhan organisasi, namun sistem masih dapat dikembangkan dengan berbagai fitur-fitur yang akan memberikan dukungan yang lebih baik kepada organisasi. Fitur-fitur yang dapat dikembangkan antara lain adalah fungsi untuk manajemen keanggotaan, manajemen keuangan dan lain-lain.

\section{Referensi}

1. Ahmad, R., \& Ali, N.A. (2004). Performance appraisal decision in Malaysian public service. International Journal of Public Sector Management, 17(1), 48-64.

2. Braund D., Silvis J. Shapiro A. Versteegh J. (2001). Object Oriented Analysis and Design Team. Kennesaw State University CSIS 4650 Spring 2001.

3. Eriksson, H. E. and M. Penker (1998). UML Toolkit, John Wiley \& Sons.

4. Huo, M., Verner, J., Zhu, L., Babar, M.A. (2004) "Software Quality and Agile Methods", Proceedings of the 28th Annual International Computer Software and Application Conference (COMPSAC '04).

5. Jiang, L., \& Eberlein, A. (2008). Towards a framework for understanding the relationships between classical software engineering and agile methodologies. APOS '08: Proceedings of the 2008 international workshop on Scrutinizing Agile practices or shoot-out at the Agile corral. APM Publishing.

6. Nerur, S. and Balijepally, V. (2007) "Theoretical reflections on agile development methods - the traditional goal of optimization and control is making way for learning and innovation', Communications of the ACM, 50 (3), 79-83. 